\title{
Relation between 25-Hydroxyvitamin D, Systemic Inflammation and Endothelial Function Biomarkers in Diabetic Nephropathy
}

\author{
Mohammed H Saiem Al-Dahr*
}

Department of Medical Laboratory Technology, Faculty of Applied Medical Sciences, King Abdulaziz University, Saudi Arabia

ISSN: 2637-7632

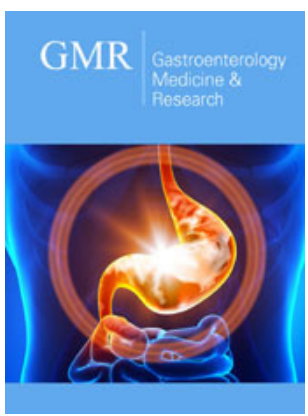

*Corresponding author: Mohammed H Saiem Al-Dahr, Department of Medical Laboratory Technology, Faculty of Applied Medical Sciences, King Abdulaziz University, Saudi Arabia

Submission: 海 October 21, 2020

Published: 眥 December 02, 2020

Volume 5 - Issue 3

How to cite this article: Mohammed H Saiem Al-Dahr. Relation between 25-Hydroxyvitamin D, Systemic Inflammation and Endothelial Function Biomarkers in Diabetic Nephropathy. Gastro Med Res. 5(3). GMR.000611. 2020. DOI: $10.31031 /$ GMR.2020.05.000611

Copyright@ Mohammed H Saiem AlDahr, This article is distributed under the terms of the Creative Commons Attribution 4.0 International License, which permits unrestricted use and redistribution provided that the original author and source are credited.

\begin{abstract}
Background: Diabetic nephropathy (DN) is a microvascular diabetic complications that leads to renal failure worldwide. However, vitamin D is essential to maintain health of vascular system.

Objective:The target of this study was to measure the association between 25 -hydroxyvitamin D, systemic inflammation and endothelial function biomarkers in patients with type 2 diabetic nephropathy.

Material and Methods: Two hundred Saudi obese type 2 diabetes mellitus (T2DM) patients (114 males and 86 females), their body mass index (BMI) was $31-35 \mathrm{Kg} / \mathrm{m} 2$ and the chronicity of diabetes was $11.87 \pm 2.95$ year enrolled in the present study. Smokers and patients with renal insufficiency, congestive heart failure, pregnancy, respiratory failure and hepatitis were excluded. Participants were enrolled into three equal groups: group (A) $25-0 H D<20 \mathrm{ng} / \mathrm{ml}$ (deficiency of vitamin D), group (B): $25-\mathrm{OHD}=20-30$ $\mathrm{ng} / \mathrm{ml}$ (insufficiency of vitamin D) and group(C) $25-\mathrm{OHD}>30 \mathrm{ng} / \mathrm{ml}$ (normal vitamin D). Consent from was signed by participants.
\end{abstract}

Results: Mean values of VCAM-1, ICAM-1, E-selectin, TNF- $\alpha$, IL- 6 and CRP were significantly greater in group (A) compared to group(B) and group(C). However, vitamin D showed a strong inverse relationship with these parameters in the three groups $(\mathrm{P}<0.05)$.

Conclusion: Level of vitamin D closely related to systemic inflammation and endothelial function biomarkers in Saudi patients with diabetic nephropathy

Keywords: Inflammatory cytokines;Diabetic nephropathy; Endothelial dysfunction; Vitamin D

\section{Introduction}

Diabetic nephropathy (DN) is a common metabolic disorder with progressive rate of morbidity and mortality worldwide [1]. However, DN is a global diabetic microvascular complication leads to renal failure [2-5]. While, DN occur in 20-40\% of type 2 diabetes mellitus (T2DM) patients and the principal etiology of renal failure [6,7]. Patients with DN suffer from high rate of morbidity and mortality. In fact, a rapid kidney function decline is a predictor for both cardiovascular disorders as well as all-cause mortality [8-10]. Risk factors of DN include poor metabolic control, diabetes duration, race, heredity, lifestyle, diet composition, aging and hypertension. On the other hand, systemic inflammation and endothelial dysfunction are 2 serious elements in promoting DN [11-13]. Vitamin D is essential for the function and health of the heart, blood vessels and kidney [14-17]. However, deficiency of vitamin D affects about $50 \%$ of worldwide population and induce many vascular complications among T2DM patients [18-20]. Therefore, this study aimed to detect the association between vitamin D, systemic inflammation and endothelial function biomarkers in patients with T2DM nephropathy.

\section{Material and Methods}

\section{Subjects}

Two hundred Saudi obese type 2 diabetes mellitus (T2DM) patients (114 males and 86 females), their body mass index (BMI) was $31-35 \mathrm{Kg} / \mathrm{m}^{2}$ and the chronicity of diabetes was $11.87 \pm 2.95$ year enrolled in the present study. Smoking, cancer, immune system disorders and pain, antidepressant, anti-inflammatory medications were the exclusion criteria. Participants were enrolled into three equal groups: group(A) 25-0HD $<20 \mathrm{ng} / \mathrm{ml}$ (deficiency of vitamin D), group(B): $25-\mathrm{OHD}=20-30 \mathrm{ng} / \mathrm{ml}$ (insufficiency of vitamin D) and group(C) $25-\mathrm{OHD}>30 \mathrm{ng} / \mathrm{ml}$ (normal vitamin D). Consent from was signed by participants. 


\section{Measurements}

A. Level of 25-hydroxyvitamin D (25-0HD) serum measurements: Overnight fasting venous blood sample was drained and was centrifuged to measure $25(\mathrm{OH})$ vitamin D for all participants. RIA (Elisa Kit; DiaSorin, Stillwater, MN, USA) was the commercial kit to measure $25(\mathrm{OH})$ vitamin D. Normal level of vitamin D is $>30 \mathrm{ng} /$ $\mathrm{ml}$, while level of $<20 \mathrm{ng} / \mathrm{ml}$ is considered as vitamin D deficiency.

B. Measurement of Adhesive molecules: Enzyme-linked immunosorbent assays (ELISAs) (R\&D Systems, France) were used to measure values of inter-cellular adhesion molecule (ICAM-1), vascular cell adhesion molecule (VCAM-1) and E-selectin.

C. Inflammatory cytokines measurements: TNF- $\alpha$ and IL-6 were measured using (GE Healthcare Amersham, Biotrak Easy ELISA). While, enzymatic-colorimetric method with kits (Roche Diagnostics, Mannheim, Germany) were used to measure C-reactive protein (CRP).

\section{Statistical analysis}

SPSS (Chicago, IL, USA) version 23 was used for statistical analysis of data. Descriptive statistics for quantitative variables were presented as mean $\pm \mathrm{SD}$, while qualitative variables were presented as percentage and numbers. Analysis of variance (ANOVA) was used to compare between the three groups, $\mathrm{P}<0.05$. While Pearson's correlation coefficients ( $r$ ) used to detect the degree of correlation between level of vitamin D and VCAM-1, ICAM-1, E-selectin, TNF- $\alpha$, IL-6 \& CRP.

\section{Results}

Participants baseline criteria of the three groups presented in (Table 1). Mean values of HDL-c, LDL-c, TC, TG, HbA1C and Creatinine revealed significant differences among the three groups. While, mean values of age and BMI revealed no significant differences among the three groups (Table 1). Mean values of VCAM-1, ICAM-1, E-selectin, TNF- $\alpha$, IL- 6 and CRP were significantly greater in vitamin $\mathrm{D}$ deficiency group (A) compared to vitamin D insufficiency group (B) and normal vitamin D group(C) (Table 2). Moreover, vitamin D showed a strong inverse relationship with these parameters in the three groups (Table 3$)(\mathrm{P}<0.05)$.

Table 1: Participants baseline criteria. BMI-Body mass index; HDL-c-High-density lipoprotein cholesterol; LDL-c-Lowdensity lipoprotein cholesterol; TG-Triglyceride; TC-Total cholesterol ; HBA1C-Glycosylated hemoglobin ; (*)-indicates a significant difference between groups, $\mathrm{P}<0.05$.

\begin{tabular}{|c|c|c|c|c|}
\hline Variable & $\begin{array}{l}\text { Group (A) } \\
\text { 25-OHD } \\
\text { Deficiency }\end{array}$ & $\begin{array}{c}\text { Group (B) } \\
\text { 25-OHD } \\
\text { Insufficiency }\end{array}$ & $\begin{array}{l}\text { Group (C) } \\
25-0 H D \\
\text { Normal }\end{array}$ & Significance \\
\hline Age (year) & $49.84 \pm 5.13$ & $51.32 \pm 5.25$ & $50.62 \pm 4.38$ & $\mathrm{P}<0.05$ \\
\hline BMI $\left(\mathrm{kg} / \mathrm{m}^{2}\right)$ & $32.36 \pm 4.32$ & $30.78 \pm 4.56$ & $31.93 \pm 4.14$ & $\mathrm{P}<0.05$ \\
\hline HDL-c (mg/dl) & $31.57 \pm 5.28^{*}$ & $34.21 \pm 5.61$ & $39.69 \pm 6.37$ & $\mathrm{P}<0.05$ \\
\hline LDL-c (mg/dl) & $178.24 \pm 26.49^{*}$ & $162.36 \pm 21.27$ & $115.49 \pm 18.65$ & $\mathrm{P}<0.05$ \\
\hline $\mathrm{TC}(\mathrm{mg} / \mathrm{dl})$ & $257.31 \pm 38.16^{*}$ & $228.53 \pm 31.35$ & $195.42 \pm 24.82$ & $\mathrm{P}<0.05$ \\
\hline $\mathrm{TG}(\mathrm{mg} / \mathrm{dl})$ & $235.25 \pm 35.74^{*}$ & $214.42 \pm 28.12$ & $168.38 \pm 21.35$ & $\mathrm{P}<0.05$ \\
\hline HbA1C (\%) & $8.57 \pm 1.43^{*}$ & $7.13 \pm 1.21$ & $4.97 \pm 0.86$ & $\mathrm{P}<0.05$ \\
\hline $\begin{array}{l}\text { Creatinine } \\
(\mu \mathrm{mol} / \mathrm{mol})\end{array}$ & $86.35 \pm 10.72 *$ & $79.26 \pm 8.68$ & $68.13 \pm 6.27$ & $\mathrm{P}<0.05$ \\
\hline
\end{tabular}

Table 2: Comparison between the three groups concerning VCAM-1, ICAM-1, E-selectin, TNF-a, IL-6 \& CRP.

\begin{tabular}{|c|c|c|c|c|}
\hline Variable & $\begin{array}{l}\text { Group (A) } \\
\text { 25-0HD } \\
\text { Deficiency }\end{array}$ & $\begin{array}{c}\text { Group (B) } \\
\text { 25-OHD } \\
\text { Insufficiency }\end{array}$ & $\begin{array}{l}\text { Group (C) } \\
25-0 H D \\
\text { Normal }\end{array}$ & Significance \\
\hline $\begin{array}{l}\text { Creatinine } \\
(\mu \mathrm{mol} / \mathrm{mol})\end{array}$ & $85.36 \pm 9.45^{*}$ & $79.24 \pm 8.32$ & $71.38 \pm 7.26$ & $\mathrm{P}<0.05$ \\
\hline ICAM-1 (ng/ml) & $91.72 \pm 10.11^{*}$ & $87.35 \pm 9.25$ & $82.52 \pm 8.17$ & $\mathrm{P}<0.05$ \\
\hline VCAM-1 (ng/ml) & $803.13 \pm 31.24^{*}$ & $775.24 \pm 28.71$ & $757.38 \pm 26.39$ & $\mathrm{P}<0.05$ \\
\hline E-selectin (ng/ml) & $15.21 \pm 3.87 *$ & $13.11 \pm 2.95$ & $11.29 \pm 2.56$ & $\mathrm{P}<0.05$ \\
\hline TNF- $\alpha(\mathrm{pg} / \mathrm{mL})$ & $10.62 \pm 3.25^{*}$ & $9.37 \pm 2.86$ & $7.28 \pm 2.23$ & $\mathrm{P}<0.05$ \\
\hline IL-6 (pg/mL) & $6.14 \pm 1.54^{*}$ & $4.43 \pm 1.21$ & $3.65 \pm 1.15$ & $\mathrm{P}<0.05$ \\
\hline CRP (mg/L) & $4.67 \pm 1.39 *$ & $3.11 \pm 1.24$ & $2.27 \pm 1.12$ & $\mathrm{P}<0.05$ \\
\hline
\end{tabular}

ICAM-1-Inter-cellular adhesion molecule; VCAM-1-Vascular cell adhesion molecule; TNF-a-Tumor necrosis factor-alpha; IL-6-Interleukin-6; CRP-C-reactive protein; (*)-indicates a significant difference between groups, $\mathrm{P}<0.05$. 
Table 3: Correlation coefficient ( $r$ ) of vitamin D and VCAM-1, ICAM-1, E-selectin, TNF-a, IL-6 \& CRP in the three groups. Spearman's correlation was used*: $\mathrm{P}<0.05^{* *}$ : $\mathrm{P}<0.01$.

\begin{tabular}{|c|c|c|c|}
\hline Variable & $\begin{array}{c}\text { Group (A) } \\
\text { 25-OHD } \\
\text { Deficiency }\end{array}$ & $\begin{array}{c}\text { Group (B) } \\
\text { 25-0HD } \\
\text { Insufficiency }\end{array}$ & $\begin{array}{c}\text { Group (C) } \\
\text { 25-0HD } \\
\text { Normal }\end{array}$ \\
\hline $\begin{array}{c}\text { Creatinine } \\
(\mu \mathrm{mol} / \mathrm{mol})\end{array}$ & $-0.742^{* *}$ & $-0.675^{*}$ & $-0.624^{* *}$ \\
\hline ICAM-1 $(\mathrm{ng} / \mathrm{ml})$ & $-0.564^{*}$ & $-0.542^{*}$ & $-0.617^{*}$ \\
\hline VCAM-1 $(\mathrm{ng} / \mathrm{ml})$ & $-0.682^{* *}$ & $-0.657^{* *}$ & $-0.521^{*}$ \\
\hline E-selectin $(\mathrm{ng} / \mathrm{ml})$ & $-0.631^{*}$ & $-0.743^{* *}$ & $-0.672^{* *}$ \\
\hline TNF- $\alpha(\mathrm{pg} / \mathrm{mL})$ & $0.728^{* *}$ & $0.612^{*}$ & $0.543^{*}$ \\
\hline $\mathrm{IL}-6(\mathrm{pg} / \mathrm{mL})$ & $0.654^{*}$ & $0.585^{*}$ & $0.641^{* *}$ \\
\hline $\mathrm{CRP}(\mathrm{mg} / \mathrm{L})$ & $0.591^{*}$ & $0.614^{* *}$ & $0.527^{*}$ \\
\hline
\end{tabular}

\section{Discussion}

Diabetic nephropathy (DN) considered as the most serious T2DM complication [21,22].While, vitamin D deficiency among T2DM patients is common [23]. Vitamin D share in regulation of insulin sensitivity and secretion and ameliorates systemic inflammation [24]. Limited information is available about relation between cardiovascular dysfunction and D deficiency among DN patients $[25,26]$. Therefore, this study aimed to detect the association between vitamin $\mathrm{D}$, systemic inflammation and endothelial function among T2DM patients nephropathy.

Results of this study indicated that vitamin D deficiency group (A) had greater significant mean values of TNF- $\alpha$, IL- 6 and CRP than group (B) and group (C) in addition to a negative relation between these systemic inflammatory parameters and vitamin $D$ level. These findings agreed with many previous studies [27,28]. Moreover, several researches proved that vitamin D deficiency related to higher inflammatory cytokines levels [29-32]. In the other hand, many previous trails on different pathological conditions stated that administration of supplemental vitamin D for different durations resulted in highly significant down regulation of inflammatory cytokines which prove the ameliorating effect of vitamin D upon the systemic inflammation [33-35].

Concerning results of endothelial function parameters, vitamin D deficiency group (A) had greater significant mean values of VCAM1, ICAM-1 and E-selectin than group (B) and group (C) in addition to a inverese relation between these parameters and vitamin $\mathrm{D}$ level. These findings approved by proved that low vitamin D was related to endothelial dysfunction [36-38]. In the other hand, many previous trails on different pathological conditions stated that administration of supplemental vitamin D for different durations resulted in highly significant improvement in endothelial function [39-43]. Renin-angiotensin system inhibition [44], vascular resistance reduction [45], inflammatory cytokines amelioration [46] and reduction of platelet aggregation [47-49] \& oxidative stress are the mechanisms that link of vitamin D and endothelial function.

\section{Conclusion}

Level of vitamin D closely related to systemic inflammation and endothelial function biomarkers in Saudi patients with diabetic nephropathy.

\section{References}

1. Whiting DR, Guariguta L, Weil C, Shaw J (2011) IDF diabetes atlas: Global estimates of the prevalence of diabetes for 2011 and 2030. Diabetes Res Clin Pract 94(3): 311-321.

2. Moradi M, Rahimi Z, Amiri S, Rahimi Z, Mahmood V, et al. (2015) AT1R A1166C variants in patients with type 2 diabetes mellitus and diabetic nephropathy. J Nephropathol 4(3): 69-76.

3. Gheith O, Farouk N, Nampoory N, Halim MA, Al-Otaibi T (2016) Diabetic kidney disease: Worldwide difference of prevalence and risk factors. J Nephropharmacol 5(1): 49-56.

4. Akbari F, Shahinfard N, Mirhoseini M, Shirzad H, Heidarian E, et al. (2016) Impacts of Hibiscus esculentus extract on glucose and lipid profile of diabetic rats. J Nephropharmacol 5(2): 80-85.

5. Adeshara KA, Diwan AG, Tupe RS (2016) Diabetes and complications: Cellular signaling pathways, current understanding and targeted therapies. Curr Drug Targets 17(11): 1309-1328.

6. Tuttle KR, Bakris GL, Bilous RW, Chiang JL, De Boer IH, et al. (2014) Diabetic kidney disease: A report from an ADA consensus conference. Diabetes Care 37(10): 2864-2883.

7. Ahn JH, Yu JH, Ko SH, Kwon HS, Kim DJ, et al. (2014) Prevalence and determinants of diabetic nephropathy in Korea: Korea national health and nutrition examination survey. Diabetes Metab J 38(2): 109-119.

8. Fox CS, Matsushita K, Woodward M, Bilo HJ, Chalmers J, et al. (2012) Associations of kidney disease measures with mortality and end-stage renal disease in individuals with and without diabetes: A meta-analysis. Lancet 380(9854): 1662-1673.

9. Levey AS, Becker C, Inker LA (2015) Glomerular filtration rate and albuminuria for detection and staging of acute and chronic kidney disease in adults: A systematic review. JAMA 313(8): 837-846.

10. Matsushita K, vander Velde M, Astor BC, Woodward M, Levey AS, et al. (2010) Association of estimated glomerular filtration rate and albuminuria with all-cause and cardiovascular mortality in general population cohorts: A collaborative meta-analysis. Lancet 375(9731): 2073-2081.

11. Badal SS, Danesh FR (2015) Diabetic nephropathy: Emerging biomarkers for risk assessment. Diabetes 64(9): 3063-3065. 
12. Rahimi Z, Mansouri O, Rahimi Z, Abbasi A (2013) AT2R-1332 G: A polymorphism and diabetic nephropathy in type 2 diabetes mellitus patients. J Renal Inj Prev 2(3): 97-101.

13. Maaten JM, Damman K, Verhaar MC, et al. (2016) Connecting heart failure with preserved ejection fraction and renal dysfunction: The role of endothelial dysfunction and inflammation. Eur J Heart Fail 18(6): 588-598.

14. McGreevy C, Williams D (2011) New insights about vitamin D and cardiovascular disease: A narrative review. Ann Intern Med 155(12): 820-826.

15. Sanchez-Niño MD, Bozic M, Córdoba-Lanús E, Valcheva P, Gracia O, et al. (2012) Beyond proteinuria: VDR activation reduces renal inflammation in experimental diabetic nephropathy. Am J Physiol Renal Physiol 302(6): F647-F657.

16. Molinari C, Uberti F, Grossini E, Vacca G, Carda S, et al. (2011) $1 \alpha$, 25-dihydroxycholecalciferol induces nitric oxide production in cultured endothelial cells. Cell Physiol Biochem 27: 661-668.

17. Liu Z, Woo J, Wu S, Ho S (2013) The role of vitamin D in blood pressure, endothelial and renal function in postmenopausal women. Nutrients 5(7): 2590-2610.

18. Mahajan M, Sharma R (2015) Current understanding of role of vitamin $\mathrm{D}$ in type 2 diabetes mellitus. International Journal of Recent Scientific Research 6(2):2602-2607.

19. Huang Y, Li X, Wang M, Ning H, Ying LA, et al. (2013) Lipoprotein lipase links vitamin $\mathrm{D}$, insulin resistance, and type 2 diabetes: A cross-sectional epidemiological study. Cardiovasc Diabetol 12: 17.

20. Bajaj S, Singh RP, Dwivedi NC, Singh K, Gupta A, et al. (2014) Vitamin $\mathrm{D}$ levels and microvascular complications in type 2 diabetes. Ind J Endocrinol and Metab 18(4): 537-541.

21. Bukhari SA, Shamshari WA, Ur-Rahman M, Zia-Ul-Haq M, Jaafar HZ (2014) Computer aided screening of secreted frizzled related protein 4 (SFRP4): A potential control for diabetes mellitus. Molecules 19(7): 10129-10136.

22. Grace BS, Clayton P, McDonald SP (2012) Increases in renal replacement therapy in Australia and New Zealand: Understanding trends in diabetic nephropathy. Nephrology (Carlton) 17(1):76-84.

23. Vaidya A, Williams JS (2012) The relationship between vitamin D and the renin-angiotensin system in the pathophysiology of hypertension, kidney disease, and diabetes. Metabolism 61(4): 450-458.

24. Mitri J, Pittas AG (2014) Vitamin D and diabetes. Endocrinol Metab Clin North Am 43(1): 205-232.

25. Liu Z, Liu L, Chen X, He W, Yu X (2014) Associations study of vitamin $\mathrm{D}$ receptor gene polymorphisms with diabetic microvascular complications: A meta-analysis. Gene 546(1): 6-10.

26. Heidari B, Nargesi AA, Hafezi-Nejad N, Sheikhbahaei S, Pajouhi A, et al. (2015) Assessment of serum 25-hydroxy vitamin D improves coronary heart disease risk stratification in patients with type 2 diabetes. Am Heart J 170(3): 573-579e575.

27. Yin K, Agrawa DK (2014) Vitamin D and inflammatory diseases. J Inflamm Res 7: 69-87.

28. Liu LC, Voor AA, Velohuisen DJ, Eveline V, Anne M, et al. (2011) Vitamin D status and outcomes in heart failure patients. Eur J Heart Fail 13(6): 619-625.

29. Hummel DM, Fetahu IS, Groschel C, Teresa M, Enikő K (2014) Role of pro-inflammatory cytokines on expression of vitamin D metabolism and target genes in colon cancer cells. J Steroid Biochem Mol Biol 144: 91-95.
30. Adegoke SA, Smith OS, Adekile AD, Figueiredo MS (2017) Relationship between serum 25-hydroxyvitamin D and inflammatory cytokines in pediatric sickle cell disease. Cytokine 96: 87-93.

31. Grudet C, Malm J, Westrin A, Brundin L (2014) Suicidal patients are deficient in vitamin $\mathrm{D}$, associated with a pro-inflammatory status in the blood. Psychoneuroendocrinology 50: 210-219.

32. Bilir B, Tulubas F, Bilir BE, Atile NS, Kara SP, et al. (2016) The association of vitamin $\mathrm{D}$ with inflammatory cytokines in diabetic peripheral neuropathy. J Phys Ther Sci 28(7): 2159-2163.

33. Mansouri L, Lundwall K, Moshfegh A, Jacobson SH, Lundahl J, et al. (2017) Vitamin D receptor activation reduces inflammatory cytokines and plasma MicroRNAs in moderate chronic kidney disease-a randomized trial. BMC Nephrol 18(1): 161.

34. Calton EK, Keane KN, Newsholme P, Soares MJ (2015) The impact of vitamin D levels on inflammatory status: A systematic review of immune cell studies. PLoS One 10(11): e0141770.

35. Navarro JF, Correa J, Mendez ML, et al. (2013) Anti-inflammatory profile of paricalcitol in hemodialysis patients: A prospective, open-label, pilot study. J Clin Pharmacol 53(4): 421-426.

36. Tarcin O, Yavuz DG, Ozben B, Telli A, Ogunc AV, et al. (2009) Effect of vitamin $\mathrm{D}$ deficiency and replacement on endothelial function in asymptomatic subjects. J Clin Endocrinol Metab 94(10): 4023-4030.

37. Jablonski KL, Chonchol M, Pierce GL, Walker AE, Seals DR (2011) 25-hydroxyvitamin D deficiency is associated with inflammation-linked vascular endothelial dysfunction in middle-aged and older adults. Hypertension 57(1): 63-69.

38. Yiu YF, Chan YH, Yiu KH, Siu CW, Li SW, et al. (2011) Vitamin D deficiency is associated with depletion of circulating endothelial progenitor cells and endothelial dysfunction in patients with type 2 diabetes. J Clin Endocrinol Metab 96(5): E830-E835.

39. Harris RA, Pedersen J, Guo DH, Stallmann IS, Keeton D, et al. (2011) Vitamin D3 supplementation for 16 weeks improves flow-mediated dilation in overweight african-american adults. Am J Hypertens 24(5): 557-562.

40. Al Mheid I, Patel R, Murrow J, Morris A, Rahman A, et al. (2011) Vitamin D status is associated with arterial stiffness and vascular dysfunction in healthy humans. J Am Coll Cardiol 58(2): 186-192.

41. Dong Y, Stallmann IS, Pollock NK, Harris RA, Keeton D, et al. (2010) A 16week randomized clinical trial of 2000 international units daily vitamin D3 supplementation in black youth: 25-hydroxyvitamin D, adiposity, and arterial stiffness. J Clin Endocrinol Metab 95(10): 4584-4591.

42. Chitalia N, Recio-Mayoral A, Kaski JC, Banerjee D (2012) Vitamin D deficiency and endothelial dysfunction in non-dialysis chronic kidney disease patients. Atherosclerosis 220(1): 265-268.

43. Mazidi M, Karimi E, Rezaie P, Vatanparast H (2017) The impact of vitamin D supplement intake on vascular endothelial function; a systematic review and meta-analysis of randomized controlled trials. Food Nutr Res 61(1): 1273574.

44. Li YC, Kong J, Wei M, Chen ZF, Liu SQ et al. (2002) 1,25-dihydroxyvitamin D3 is a negative endocrine regulator of the renin-angiotensin system. J Clin Investig 110(2): 229-238.

45. Norman P, Powell J (2005) Vitamin D, shedding light on the development of disease in peripheral arteries. Arterioscler Thromb Vasc Biol 25(1): $39-46$.

46. Zehnder D, Bland R, Chana R, Wheeler D, Howie A, et al. (2002) Synthesis of 1,25-dihydroxyvitamin D3 by human endothelial cells is regulated by inflammatory cytokines: A novel autocrine determinant of vascular cell adhesion. J Am Soc Nephrol 13(3): 621-629. 
47. Molinari C, Uberti F, Grossini E, Vacca, Carda S, et al. (2011) $1 \alpha, 25$ dihydroxycholecalciferol induces nitric oxide production in cultured endothelial cells. Cell Physiol Biochem 27(6): 661-668.

48. Aihara K, Azuma H, Akaike M, Ikeda Y, Yamashita M, et al. (2004) Disruption of nuclear vitamin D receptor gene causes enhanced thrombogenicity in mice. J Biol Chem 279(34): 35798-35802.

49. Urena Torres P, Metzger M, Haymann JP, Karras A, Boffa J, et al. (2011) Association of kidney function, vitamin D deficiency, and circulating markers of mineral and bone disorders in CKD. Am J Kidney Dis 58(4): 544-553.

For possible submissions Click below: 